\title{
Peran Guru Pedidikan Agama Islam Dalam Mengatasi Kesulitan Peserta Didik Membaca Alquran Di SMA Negeri 1 Merawang Kabupaten Bangka
}

\author{
Yudi Iskandar' ${ }^{1}$ Rosidi², Misbahul munir ${ }^{3}$ \\ 1IAIN Syaikh Abdurrahman Siddik \\ 2IAIN Syaikh Abdurrahman Siddik \\ ${ }^{3}$ IAIN Syaikh Abdurrahman Siddik
}

\begin{tabular}{l}
\hline Info Artikel : \\
\hline Diterima 3 Januari 2020 \\
Direvisi 12 Januari 2020 \\
publikasikan 22 Januari2020 \\
\\
Kata Kunci: \\
Pendidikan Agama Islam, \\
Kesulitan Membaca Alquran
\end{tabular}

Keywords:

Islamic Education

Reading Al Quran

\begin{abstract}
ABSTRAK
Peran Guru Agama Islam merupakan hal yang terpenting dalam melakukan tindakan yang nyata seorang guru untuk melakukan perbaikan dalam suatu kejadian. Adapun penelitian ini bertujuan untuk mendeskripsikan Peran guru Pendidikan Agama Islam di SMA Negeri 1 Merawang Kabupaten Bangka dalam mengatasi kesulitan peserta didik membaca Alquran di SMA Negeri 1 Merawang Kabupaten Bangka. Jenis penelitian yang dilakukan ini adalah jenis penelitian kualitatif. Dalam proses pengumpulan data, peneliti menggunakan beberapa metode yaitu metode observasi, wawancara, dan dokumentasi. Sedangkan untuk teknik analisis data peneliti menggunakan teknik analisis deskriptif kualitatif. Hasil penelitian ini menunjukan bahwa peran guru pendidikan agama Islam di SMA Negeri 1 Merawang dalam mengatasi kesulitan peserta didik dalam membaca Alquran sangat beragam dan bervariasi diantaranya membuat suatu ekskul (ekstra kurikuler) rohis, mengadakan one day one juz. Dalam ekskul (ekstra kurikuler) rohis ada tiga pengajaran dalam mengatasi kesulitan membaca Alquran bagi peserta didik, yang pertama peserta didik diarahkan untuk belajar hukum bacaan atau ilmu tajwid, yang kedua peserta didik diajarkan tilawah Alquran, yang ketiga peserta didik diajarkan tahfidz Alquran. Dengan ini guru Pendidikan Agama Islam dapat mengatasi kesulitan peserta didik dalam membaca Alquran.
\end{abstract}

\begin{abstract}
The Role of Islamic Teachers is the most important thing in carrying out a teacher's concrete actions to make improvements in an incident. The purpose of this research is to describe the role of Islamic Religious Education teachers in SMA Negeri 1 Merawang, Bangka Regency in overcoming the difficulties of students reading the Koran in SMA Negeri 1 Merawang, Bangka Regency. This type of research conducted is a type of qualitative research. In the process of collecting data, researchers use several methods, namely observation, interviews, and documentation. As for the data analysis technique, the researchers used a qualitative descriptive analysis technique. The results of this study indicate that the role of Islamic religious education teachers at SMA Negeri 1 Merawang in overcoming the difficulties of students in reading the Koran is very diverse and varied including making an extracurricular (extracurricular) spiritist, holding one day one juz. In spiritual (extra-curricular) extracurriculars there are three teachings in overcoming the difficulty of reading the Koran for students, the first students are directed to study the law of recitation or recitation, the second the students are taught under the Qur'an, the third students are taught tahfidz Alquran. With this Islamic Religious Education teacher can overcome the difficulties of students in reading the AlQuran
\end{abstract}

This is an open access article distributed under the Creative Commons Attribution License, which permits unrestricted use, distribution, and reproduction in any medium, provided the original work is properly cited. (C2019 by author.

\section{Koresponden:(9 pt)}

Yudi Iskandar

Email: yudiiskandar17@gmail.com 
Pendidikan adalah sebuah proses pembelajaran melalui kegiatan formal, yang tujuannya tidak lain adalah untuk pengembangan diri individu, untuk menguasai berbagai aspek baik kognitif, afektif dan psikomotorik. Kegiatan pendidikan bukan hanya dilakukan dan difasilitasi oleh guru di sekolah tetapi juga oleh orang tua, keluarga dan lingkungan. ${ }^{1}$

Dalam Undang-undang no. 20 tahun 2003 tentang Sisdiknas, dikemukakan bahwa yang dimaksud dengan guru atau pendidik merupakan tenaga profesional yang bertugas merencanakan dan melaksanakan proses pembelajaran, menilai hasil pembelajaran, melakukan pembimbingan dan pelatihan, serta melakukan penelitian dan pengabdian kepada masyarakat. ${ }^{2}$ Berdasarkan uraian tentang definisi guru dan Pendidikan Agama Islam dapat dipahami bahwa guru Pendidikan Agama Islam yaitu guru atau tenaga pendidikan yang secara berkelangsungan mentranformasikan ilmu dan pengetahuannya terhadap peserta didik di sekolah, dengan tujuan agar para peserta didik tersebut menjadi pribadi-pribadi yang berjiwa Islami. Untuk bab-bab berikutnya peneliti menyingkat kata pendidikan agama Islam menjadi PAI.

Dari pengertian di atas, guru mempunyai peran yang penting. Sebab guru adalah orang yang kerjanya mengajar, membimbing, mengarahkan, melatih, menilai, dan mengevaluasi peserta didik. Peran guru, khususnya guru Agama Islam sangat besar konstribusinya dalam melaksanakan proses pembelajaran di dalam kelas, setidaknya akan membentuk sikap siswa dalam belajar, dan bagi guru sendiri ialah sebagai alat untuk mencapai tujuan pelajaran.

Keberhasilan proses pembelajaran merupakan suatu harapan, baik guru maupun peserta didik. Salah satu faktor yang dijadikan ukuran keberhasilan dalam proses pembelajaran adalah perubahan perilaku siswa dalam minat belajar siswa yang tinggi. Secara konseptual, peranan guru dalam proses pembelajaran meliputi banyak hal antara lain sebagai model, manajer kelas, mediator, komunikasi, fasilitator dan evaluator. ${ }^{3}$.

Hal ini menunjukan bahwa guru Agama Islam melakukan perannya diantaranya yaitu sebagai pengajar, pengelola kelas, motivator, dan evaluator. Dalam proses belajar membaca Alquran tidak akan berjalan lancar tanpa ada yang mengajari tentang belajar membaca Alquran dan orang yang memonitornya atau membimbingnya yaitu guru, khususnya guru Pendidikan Agama Islam. Dalam proses membaca Alquran, guru merupakan salah satu komponen penting yang memiliki tugas, tanggung jawab dan peran secara langsung untuk mengatasi kesulitan membaca Alquran peserta didik sehingga tujuan belajar membaca Alquran tercapai. ${ }^{4}$

\section{METODE}

Adapun jenis penelitian yang digunakan penulis dalam penelitian ini adalah penelitian kualitatif. Hal ini selain dengan pendapat Ahmad Tanzeh yang mendefinisikan bahwa penelitian kualitatif adalah suatu bentuk penelitian yang dimaksudkan untuk mengungkap gejala secara holistik-kontekstual (secara menyeluruh dan sesuai dengan kontek/apa adanya) melalui pengumpulan data dari latar alami sebagai sumber langsung. ${ }^{5}$ Tempat pelaksanaan penelitian dilakukan di SMA Negeri 1 Merawang Kabupaten Bangka. Waktu yang digunakan dalam penelitian yang berjudul, "Peran Guru PAI dalam Mengatasi Kesulitan Peserta didik Membaca Alquran di SMA Negeri 1 Merawang Kabupaten Bangka", yakni dimulai sejak dikeluarkannya surat izin penelitian oleh Rektor IAIN Syaikh Abdurrahman Siddik Bangka Belitung sampai dengan selesai.

Muhammad Idrus menjelaskan data adalah segala keterangan (informasi) mengenai semua hal yang berkaitan dengan tujuan penelitian. Dengan demikian, tidak semua informasi atau keterangan merupakan data penelitian. Dalam penelitian kualitatif dan dapat diartikan sebagai fakta atau informasi yang diperoleh dari aktor (subjek penelitian, informan, pelaku), aktivitas dan tempat yang menjadi subjek penelitiannya. ${ }^{6}$

Dalam penelitian ini peneliti menggunakan metode wawancara, observasi dan dokumentasi Wawancara Metode Observasi, Metode Dokumentasi. Teknik dokumentasi ini diperlukan untuk melengkapi data observasi dan wawancara, berupa foto-foto, dokumen Sekolah, catatan tentang data mengenai sejarah singkat dan profil Sekolah, visi dan misi, keadaan tenaga pendidik dan peserta didik, struktur organisasi, serta sarana dan prasarana. Analisis data yang digunakan dalam penelitian ini adalah analisis data deskriptif.7 Teknik analisis data yang digunakan dalam penelitia ini adalah teknik analisis data deskriptif.

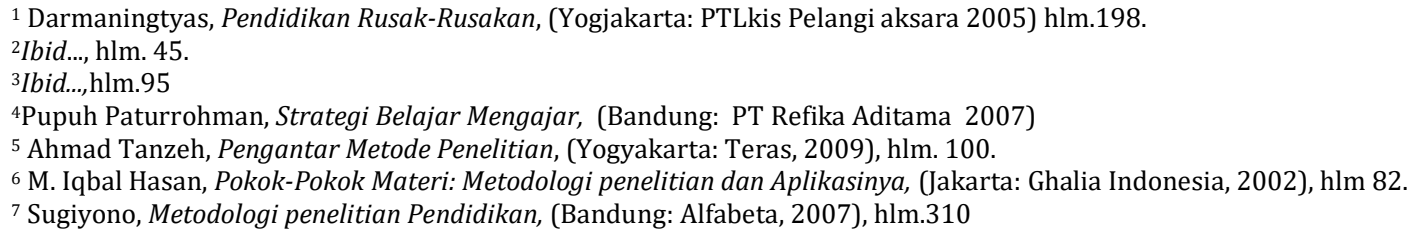




\section{HASIL DAN PEMBAHASAN}

Problematika yang dialami peserta didik saat membaca Alquran di SMA Negeri1 Merawang Untuk kemampuan membaca banyak dari peserta didik disini masih dikatakan kurang atau sebagian besar masih kurang lancar membaca Alquran. Rata-rata dari peserta didik yang kami observasi mereka sebagian sudah bisa mengenal huruf, membaca dengan baik, dan mengenal huruf hijaiyah. Pelafalan dan pengucapan huruf menjadi kesulitan terbesar yang dialami oleh peserta didik di sini. Bapak Senan sebagai salah satu guru PAI beliau mengatakan : "peserta didik di sini sulit untuk melafalkan, mengingat huruf, membedakan dan terlebih lagi membedakan tajwid dalam bacaan"8

Hal ini serupa dengan beberapa pendapat dari peserta didik yang sempat saya beri pertanyaan tentang bagaimana kesulitan terhadap membaca Alquran, disampaikan oleh siswa bahwa : "saya masih sulit untuk membedakan bunyi huruf-huruf yang hampir sama dan sulit untuk tahu hukum-hukum tajwidnya, karena saya terakhir belajar membaca Alquran semenjak sudah lulus dari TPA, dan semenjak saya sudah lulus saya tidak pernah lagi membaca dan belajar Alquran, jadi apa yang disampaikan oleh para ustadz saya dulu kebanyakan sudah lupa"9

Jika di atas tadi saya menyebut beberapa kesulitan yang ditemui peserta didik saat ataupun ketika membaca Alquran mulai dari kesulitan mengenali bunyi huruf yang sama sampai sulit untuk meluangkan waktu untuk belajar membaca Alquran, maka suasana hati menjadi penyabab yang banyak diutarakan oleh peserta didik di SMA Negeri 1 merawang ini untuk tidak membaca Alquran. Dan juga apabila mereka ada kegiatan atau perlombaan di sekolah mereka akan meninggalkan pelajaran Alquran tersebut, demi lancarnya acara mereka yang diadakan oleh sekolah. Seperti apa yang disampaikan oleh salah satu peserta didik ini bahwa : "Apabila ada acara lain seperti perlombaan, kesenian, acara-acara besar seperti tujuh belas agustus dan hari-hari besar lainnya, maka kami tidak bisa mengikuti pelajaran Alquran, jadi terpaksa kami tinggalkan pelajaran Alqurannya demi kelancaran acara tersebut"10

Untuk permasalahan pada peserta didik saat belajar membaca Alquran yang saya temukan akhir ini menjadi sesuatu yang menarik untuk difikirkan. Mereka mengatakan tidak bisa belajar Alquran karena banyak kegiatan, terhadap dari pertanyaan yang saya berikan kepada peserta didik tentang kesulitan membaca Alquran. Dengan banyaknya kegiatan yang ada di SMA Negeri 1 Merawang menjadi penyebab siswa belajar membaca Alquran, karena terbenturnya kegiatan lain dengan pelajaran Alquran. Walaupun pelajaran Alquran ini di luar jam pelajaran tetapi sering terbentur dengan kegiatan lain karena saat jam pulang, baru mereka bisa latihan untuk acara yang mereka laksanakan. Hal ini menyebabkan terbenturnya pelajaran Alquran dan latihan untuk acara mereka tersebut. ${ }^{11}$

Tetapi jika diamati lebih dalam lagi, maka kesulitan terbesar yang dialami oleh peserta didik di sekolah ini adalah niat. Niatan untuk belajar dan membiasakan untuk membaca Alquran. Walaupun masih sangat jauh untuk dikatakan lancar dalam membaca Alquran, tapi kalau niat itu ada dan diwujudkan maka akan sangat membantu mereka dalam belajar membaca Alquran. Dari observasi yang saya lakukan. Niat inilah yang hilang dari peserta didik, niat untuk belajar dan niat untuk mengamalkan apa yang dipelajari. Membaca Alquran seharusnya bukan menjadi hal yang sulit untuk peserta didik di sekolah ini yang hampir keseluruhan dari mereka yang pernah belajar membaca Alquran diwaktu kecil mereka. Tapi hal ini menjadi sulit karena sebagian mereka tidak lagi mempraktikkan belajar membaca Alquran yang mereka peroleh ketika masih anak-anak.

Kesulitan yang saya temui terhadap peserta didik bukan hanya kesalahan peserta didik sebelumnya atau sebelum peserta didik ini sekolah di SMA Negeri 1 Merawang, melainkan dari faktor luar dan faktor dalam peserta didik itu sendiri. Seperti halnya peran orang tua yang dituntut untuk senantiasa membentengi agama dalam diri anak, karena madrasah pertama yang dikenal anak adalah keluarga terutama seorang ibu, jika pendidikan agama yang baik maka nantinya anak tersebut akan baik dalam menerima pelajaran yang diberikan oleh seorang guru terutama tentang pendidikan agama Islam karena orang tua yang sudah memberikan contoh dan arahan yang baik untuk anaknya.

Lingkungan juga berpengaruh terhadap anak, lingkungan yang baik akan membantu anak untuk menerima pelajaran yang tidak ditemui dilingkup keluarga, seperti adanya lingkungan mengarahkan anak untuk hal agama seperti TPA, mengaji bareng di masjid, atau bimbel belajar di rumah-rumah, kegiatan semacam ini akan sangat berpengaruh terhadap sikis anak dan perkembangan dirinya untuk lebih baik karena setiap langkahnya terbentengi oleh agama, tapi terkadang lingkungan juga memberikan pengaruh buruk terhadap anak yang seharusnya belajar untuk membaca Alquran dengan lingkungan yang tidak

${ }^{8}$ Senan, Guru Pendidikan Agama Islam kelas XII SMA Negeri 1 Merawang, Wawancara, Baturusa, 10 Oktober 2019.

'Zahwa, Siswi kelas X SMA Negeri 1 Merawang, Wawancara, Baturusa, 11 Oktober 2019.

${ }^{10}$ Richo Hardiansyah, Siswa kelas XI SMA Negeri 1 Merawang, Wawancara, Baturusa, 11 Oktober 2019.

11 Observasi, di Sekolah Menengah Atas Negeri 1 Merawang, 11 Oktober 2019. 
tersedianya dan tidak adanya inisiatif warga/ lingkungan sekitar membuat anak menjadi buta huruf akan Alquran yang tidak diterimanya sejak kecil. ${ }^{12}$

Perkembangan guru Pendidikan agama Islam dalam mengatasi kesulitan membaca Alquran di SMA Negeri 1 Merawang. Sejauh yang di temukan dari penelitian, pengamatan dan observasi peran guru agama Islam dalam mengatasi kesulitan membaca Alquran di SMA Negeri 1 Merawang kepada peserta didiknya adalah sudah sangat baik. Tapi untuk taraf seberapa keberhasilannya metode yang difokuskan oleh guru agama sudah cukup baik, dan untuk guru yang lain sudah cukup pula, tapi belum ada evaluasi buku yang digunakan oleh guru disini.

Dapat dilihat dari pernyataan disampaikan dari waka kesiswaan bapak Arif yang menggunakan pengamatan secara pribadi dan melihat dengan sendiri perkembangan perserta didiknya saat belajar bersama guru di musholla tentang membaca Alquran dengan metode yang berbeda-beda yang inisiatif dari guru itu sendiri, ${ }^{13}$ Jika pengamatan yang dipilih bapak Arif selaku waka kesiswaan sebagai cara untuk mengetahui perkembangan peserta didik untuk membaca Alquran, beda lagi dengan evaluasi yang dilakukan oleh bapak Fasky untuk melihat perkembangan peserta didik pada kelas sepuluh dan sebelas IPS dan MIPA.

Beliau menggunakan praktik membaca Alquran pada peserta didik sebelum memulai pemberian LKS (Lembar Kerja Siswa) pada siswa, tidak harus banyak tetapi hanya untuk melihat sejauh mana peserta didik berkembang, selain menggunakan model evaluasi yang berubah-rubah masih banyak hal lain yang perlu diperhatikan oleh guru maupun peserta didik dalam melakukan pembelajaran membaca Alquran. $\cdot{ }^{14}$ Karena sekolah SMA Negeri 1 Merawang bukan sekolah yang berbasis agama Islam maka untuk pelajaran agama yang tidak dipisah-pisah seperti sekolah agama Islam, tapi menjadi satu kesatuan yang diberi nama pendidikan agama Islam. Jika di sekolah dengan berbasis Islam maka pelajaran membaca Alquran akan ada mata pelajarannya tersendiri yaitu mata pelajaran Alquran dan hadis. Tetapi jika di sekolah SMA Negeri 1 Merawang pelajaran agama Islam dijadikan satu dengan mata pelajaran pendidikan agama Islam.

Dari sudut ini dapat kita cermati bahw waktu yang tersedia untuk seorang guru PAI di SMA Negeri 1 Merawang untuk membantu peserta didik yang kesulitan membaca Alquran lebih sedikit dari pada sekolah yang berbasis Islam, dalam hal ini SMA Negeri 1 Merawang sudah menggunakan k13, untuk waktu yang disediakan masih sama 120 untuk setiap guru, setiap waktu itu terpotong untuk membantu siswa dalam mengatasi kesulitan membaca Alquran sebelum dimulainya materi pembelajaran. ${ }^{15}$

Pertemuan hanya dua jam setiap kelas serta banyaknya materi dalam satu semester membuat seorang guru agama di SMA Negeri 1 Merawang tidak bisa terus fokus untuk memberikan arahan terhadap pesera didik mereka yang masih mengalami kesulitan ketika membaca Alquran.

Kemudian semenjak telah diadakan pelajaran diluar jam sekolah sebagai pelajaran tambahan bagi peserta didik yang ingin belajar membaca Alquran. Kegiatan ini bertujuan agar peserta didik dapat membaca Alquran dengan cepat. Pelajaran tambahan diluar jam sekolah ini biasanya disebut dengan ekskul (ekstra kurikuler) rohis. Dalam pelajaran tambahan ini ada beberapa jenis pelajaran Alquran yang diterapkan oleh guru pendidikan agama Islam, seperti belajar tilawah Alquran yaitu peserta didik diajarkan oleh seorang ustadz bukan guru agamnya, karena bapak Senan telah menyerahkan kepada para ustadz untuk mengajarkan Alquran agar peserta didik lebih cepat bisa membaca Aquran karena belajar dengan orang yang lebih tau dibidangnya yaitu ustadz Abdul ghoni, beliau mengajarkan bagaimana cara membaca Alquran dengan santai dan menggunakan irama yang merdu. ${ }^{16}$

Selain ustadz Abdul ghoni adalagi ustad yang mengajarkan Tahfidz yaitu ustadz Junaidi, beliu juga diamanahkan oleh bapak Senan untuk mengajarkan tentang Alquran dibidang tahfidz. Dalam memberi pengajaran dalam menghafal Alquran ustadz Junaidi berharap selain menghafal Alquran peserta didik juga bisa membaca Alquran dengan lancar dan baik sesuai dengan kaidah hukum bacaannya. ${ }^{17}$

Menggunakan metode menghafal dan Halaqoh saat belajar tilawah dan tahfidz quran dipilih agar peserta didik khususnya bai siswa yang belum begitu lancar bisa mendengar dan melihat temannya dengan membaca bersama berbentuk lingkaran. Kegiatan membaca Alquran diluar jam pelajaran ini dilakukan setelah pulang sekolah, yang berlangsng kurang lebih satu jam untuk satu pertemuan dan ada tiga pertemuan dalam satu minggu. ${ }^{18}$

\footnotetext{
12 Observasi, di Sekolah Menengah Atas Negeri 1 Merawang, 14 Oktober 2019

13 Observasi, di Sekolah Menengah Atas Negeri 1 Merawang, 14 Oktober 2019.

${ }^{14}$ Observasi, di Sekolah Menengah Atas Negeri 1 Merawang, 15 Oktober 2019.

15 Observasi, di Sekolah Menengah Atas Negeri 1 Merawang, 17 Oktober 2019.

16 Observasi, di Sekolah Menengah Atas Negeri 1 Merawang, 18 Oktober 2019.

17 Observasi, di Sekolah Menengah Atas Negeri 1 Merawang, 22 Oktober 2019.

18 Observasi, di Sekolah Menengah Atas Negeri 1 Merawang, 23 Oktober 2019.
} 
Tapi jika kita pahami lagi, guru merupakan daya tarik terbesar yang membuat peserta didik tersebut mau belajar, bapak Senan adalah sosok guru yang dihormati oleh muridnya memang umur beliau tidak muda lagi tetapi beliau mempunyai integritas dan profesional dalam mendidik siswanya, beliau adalah guru yang membuat sesuatunya menjadi pas sehingga peserta didik lebih mudah memahami apa yang dijelaskan beliau.

Bapak Senan Mengatakan :"sebenarnya sudah banyak kegiatan yang kami buat untuk peserta didik untuk mereka supaya lancar membaca Alquran, dari mulai kegiatan one day one juz tetapi kegiatan ini sudah jarang dilakukan, kegiatan ekskul (ekstra kurikuler) rohis tilawah dan tahfidz quran yang sekarang masih berjalan dengan aktif. Dengan kegiatan inilah kami bisa membuat para siswa bisa membaca Alquran dengan lancar serta menghafalnya. Jadi, inilah solusi saat ini yang bisa membuat siswa belajar membaca Alquran dengan baik dan benar".19

Banyak usaha yang dilakukan oleh guru pendidikan agama Islam di SMA Negeri 1 Merawang Kabupaten Bangka baik sebagai profesional sebagai guru maupun sebagai sesama muslim dalam membantu peserta didik untuk membaca Alquran. Walaupun sudah banyak usaha yang dikerahkan seorang guru tapi jika peserta didik yang diarahkan tidak mau untuk mengikuti arahan tersebut akan membuat apa yang telah guru lakukan menjadi kurang bermakna. Karena belajar adalah sebuah proses dari yang tidak tau menjadi tau. Belajar akan berhasil jika peserta didik sadar akan pentingnya ilmu yang mereka pelajari saat ini. Hal inilah yang masih berusaha untuk memahamkan peserta didik supaya apa yang mereka peroleh saat ini dapat dirasakan suatu saat nanti. ${ }^{20}$

Peserta didik agar lebih tau dan mengerti akan sekecil ilmu yang mereka dapat akan berguna suatu saat nanti untuk masa depan mereka kelak. Solusi yang diberikan oleh guru untuk peserta didik di mana usaha tersebut yang harus diapresiasi oleh banyak pihak karena usaha mereka tidak ringan untuk mencerdaskan peserta didik tanpa lelah dan meyakini usaha mereka akan berbuah hasil untuk mengatasi kesulitan membaca Alquran di SMA Negeri 1 Merawang Kabupaten Bangka.

\section{A. Peran Guru PAI Dalam Mengatasi Kesulitan Peserta Didik Membaca Alquran}

Pada bagian ini peneliti akan memberikan analisis tentang data yang sudah disampaikan pada babbab sebelumnya. Untuk memudahkan analisis, maka akan disusun sesuai dengan pokok masalah. Berdasarkan hasil observasi dan wawancara di SMA Negeri 1 Merawang ditemukan peran guru pendidikan agama Islam mengatasi kesulitan membaca Alquran, sekolah SMA Negeri 1 Merawang mempunyai dua guru agama Islam, dari kedua guru tersebut tidak mengajar di kelas yang sama melainkan dibagi pertingkatan, setiap tingkatan berbeda cara untuk menggunakan metode pengajaran sesuai dengan kemampuan peserta didik di kelas itu. Dari tingkatan yang paling bawah akan berbeda dengan tingkatan yang di atasnya, karena guru mencari kelebihan setiap anak dan bagaimana metode yang digunakan dapat membantu siswa dalam menerima apa yang diberikan oleh guru terutama dalam ranah membaca Alquran yang sangat dibutuhkan peserta didik saat ini.

Walaupun mempunyai perbedaan dalam proses pembelajaran tapi peningkatan kualitas peserta didik tetap menjadi tujuan yang utama. Diantara hal-hal yang penting yang dibutuhkan oleh seorang guru dalam mengatasi kesulitan peserta didik membaca Alquran adalah mencari metode yang paling tepat untuk mengajarkan Alquran kepada peserta didik mereka. Sebab, metode yang digunakan dalam mendidik peserta didik dikelas dengan mengikuti kurikulum yang telah ada dalam pelajaran pendidikan agama Islam itu hanya sekedarnya saja dalam mempelajari Alquran. Oleh karena itu pengajaran Alquran merupakan fondasi utama dalam Islam yang harus ditanamkan pada diri anak-anak agar mereka tumbuh sesuai dengan fitrah dan hati mereka bersinar cerah tanpa adanya cahaya yang masuk kedalam hati mereka karena tidak mendapat kebenaran dan manfaat membaca Alquran. ${ }^{21}$

Berikut beberapa usaha yang dilakukan oleh guru pendidikan agama Islam pada kelas sebelas SMA Negeri 1 Merawang untuk membantu peserta didik mereka dalam belajar membaca Alquran :

1. Menyediakan waktu bagi peserta didik untuk belajar membaca Alquran.Waktu dan kesempatan untuk peserta didik mengenal Alquran sangat diperlukan, meskipun peserta didik telah mengikuti pembelajaran pendidikan agama Islam di kelas hal ini sangat kecil kemungkinan bagi peserta didik untuk dapat mempelajari Alquran dengan serius. Jadi setiap guru berusaha untuk memberi yang terbaik buat peserta didiknya, terutama dalam hal membaca Alquran mereka berfikir kalau anakanak bisa dengan pandai membaca Alquran nanti mereka bisa merasakan ketika sudah lulus sekolah. Karena dengan peran gurulah peserta didik dapat terbantu akan kesulitan-kesulitan yang mereka hadapi asalkan ada timbal yang mereka berikan terhadap guru, yaitu menghilangkan rasa malas dari diri mereka, sesalu bermotivasi untuk bisa karena dengan niat untuk bisa, maka akan ada jalan untuk mendapatkannya.

${ }^{19}$ Senan, Guru Pendidikan Agama Islam kelas XII SMA Negeri 1 Merawang, Wawancara, Baturusa, 25 Oktober 2019.

20 Observasi, di Sekolah Menengah Atas Negeri 1 Merawang, 25 Oktober 2019.

${ }^{21}$ Observasi, di Sekolah Menengah Atas Negeri 1 Merawang, 25 September 2019. 
2. Memilih metode yang tepat untuk belajar membaca Alquran. Karena SMA Negeri 1 Merawang mempunyai tenaga pengajar dua orang yang setiap guru mengampu pertingkatan kelas maka apa yang diberikan untuk mengatasi kesulitan-kesulitan peserta didik yang berbeda dengan satu guru dengan yang satunya lagi. dalam teori Decision Making yaitu tahap dimana seseorang atau kelompok melakukan aktifitas yang mengarah kepada keputusan untuk menerima atau menolak inovasi tersebut. Dalam hal ini inovasi yang diberikan oleh guru sesuai dengan apa yang menjadi kesepakatan bersama, dan sudah sesuai dengan pengamatan guru terhadap peserta didik. ${ }^{22} \mathrm{Hal}$ tersebut dikatakan oleh bapak Senan karena bapak Senan menyerahkan kepada kedua ustadz tersebut untuk mengajarkan tentang Alquran diluar mata pelajaran pendidikan agama Islam, karena didalam pelajaran pendidikan agama Islam tidak ada pelajaran tentang Alquran, kalaupun ada itu hanya pelajaran dasar Alquran di semester awal pertemuan. Selain para peserta didik menghafal Alquran dengan ustadz junaidi bapak senan juga mengadakan pelajaran Alquran yaitu belajar tilawah atau belajar membaca Alquran dengan irama dan suara yang indah. Tentu ini juga seorang pengajar menggunakan metode dalam mengajarkan tilawah tersebut. Dari hasil kombinasi tersebut siswa yang mengikuti pelajaran tersebut dapat membaca atau menghafal sesuai dengan pelajaran yang mereka ikuti dan apa saja yang disampaikan oleh guru yang mengajari Alquran tersebut. Pelajaran Alquran ini pun tidak langsung dalam satu pertemuan, tapi bertahap sampai semua peserta didik yang mengikuti pelajaran tersebut dapat membaca dengan baik. ${ }^{23}$

3. Menciptakan tempat belajar yang religius. Pemilihan tempat belajar yang tepat mendukung keberhasilan proses pembelajaran yang dilakukan. Jika tempat yang digunakan tepat maka guru tidak perlu usaha yang lebih untuk membuat peserta didik mau untuk belajar. Teori ini disebut dengan Principles of Reaction yaitu menggambarkan bagaimana seharusnya guru memandang, memerlakukan, dan merespon peserta didik. Dalam hal ini guru menfasilitasi peserta didik agar menunjang dalam suasana belajar dan teori yang ingin di ajarkan guru untuk peserta didik. ${ }^{24} \mathrm{Hal}$ ini yang menarik bisa ditemukan dalam proses pembelajaran mengajar di SMA Negeri 1 Merawang khusus kelas satu dan dua lebih banyak belajar Alquran di luar kelas. Tepatnya di musholla yang dikhususkan untuk peserta didik untuk belajar membaca Alquran dan untuk peserta didik belajar praktek mengkafani jenazah dan menyholati jenazah. SMA Negeri 1 Merawang mempunyai musholla sekolah yang layak digunakan sebagai tempat ibadah maupun tempat belajar di luar kelas. Musholla yang cukup luas, bersih dan rapi cukup nyaman untuk digunakan dalam pembelajaran Alquran. Kenapa musholla menjadi tempat yang nyaman untuk pembelajaran?. Banyak alasan yang mendukung musholla dipilih oleh bapak Senan untuk melakukan proses pembelajaran. Dari tempat yang terawat sampai dengan fasilitas yang tersedia. Tempat wudhu yang memadai memudahkan peserta didik untuk mengambil air wudhu sebelum mereka membaca Alquran. Dan ketika peserta didik mau membaca Alquran sudah tidak perlu membawa dari rumah, karena di musholla sudah ada banyak dan tinggal peserta didik yang memanfaatkan fasilitas yang sudah ada untuk belajar bersama.

Menumbuhkan atmosfer religius dalam pembelajaran agama sangat penting. Guru maupun peserta didikakan melakukan proses belajar mengajar dengan lebih baik dan berkesan. Suasana yang seperti inilah yang ingin dicoba dibuat oleh bapak Senan. Suasana yang religius untuk belajar agama. Pembelajaran di kelas akan terasa kaku dan membosankan. Lain halnnya jika belajar di musholla. Suasana di musholla akan memberikan sesuatu yang berbeda dengan yang di kelas yang pada tingkat selanjutnya diharapkan dapat mengubah sisi religius peserta didik menjadi lebih baik. ${ }^{25}$

\section{KESIMPULAN}

Sesuai data hasil penelitian serta analisa peneliti mengenai Peran Guru Pendidikan Agam Islam dalam Mengatasi Kesulitan Peserta Didik Membaca Alquran di SMA Negeri 1 Merawang Kabupaten Bangka tahun 2018/2019, maka dapat diambil keimpulan sebagai berikut :

1. Problematika yang dialami peserta didik di sekolah ini amat beragam. Mulai ketika mengaji masingmasing peserta didik memiliki kesulitan. Di mulai dari waktu yang tidak tersedia, suasana hati yang sangat buruk, banyaknya eskul dan kegiatan lainnya membuat program belajar Alquran menjadi kurang efektif karena terbenturnya waktu saat belajar dan kegiatan lainnya membuat peserta didik tidak bisa fokus pada pelajaran Alquran di SMA Negeri 1 Merawang. Peserta didik yang telah mengikuti pelajaran Alquran akan meninggalkan jam pelajaran Alqurannya karena terbenturnya dengan kegiatan

\footnotetext{
22 Observasi, di Sekolah Menengah Atas Negeri 1 Merawang, 26 September 2019.

23 Observasi, di Sekolah Menengah Atas Negeri 1 Merawang, 04 Oktober 2019.

24 Observasi, di Sekolah Menengah Atas Negeri 1 Merawang, 07 Oktober 2019.

25 Observasi, di Sekolah Menengah Atas Negeri 1 Merawang, 07 Oktober 2019.
} 
lainnya. Maka dari itu pihak sekolah mestinya perlu perhatian terhadap program pelajaran dan kegiatan yang telah dibuat, agar nantinya bisa teratur antara pelajaran Alquran dan kegiatan-kegiatan yang ada.

2. Peran Guru PAI dalam mengatasi kesulitan peserta didik membaca Alquran menurut siswa peran guru PAI sudah sangat optimal. Dengan banyaknya usaha yang telah dilakukan seharusnya kemampuan peserta didik dalam membaca Alquran semakin baik. Tapi yang namanya beajar itu terjadi dua arah. Antara yang belajar dan yang memberi ilmu. Jika yang aktif salah satu pihak, maka pembelajaran yang dilakukan tidak akan optimal. Guru sudah melakukan banyak usaha untuk membantupara peserta didiknya yang masih mengalami kesulitan dalam membaca Alquran tapi sebagian dari peserta didik belum ada minat untuk belajar. Mereka mengetahui bahwa kemampuan membaca mereka masih kurang tapi kemauan mereka masih kurang tapi sebagian dari peserta didik belum ada minat untuk belajar. Mereka mengetahui bahwa kemampuan membaca mereka masih kurang tapi kemuan mereka untuk belajarinilah yang belum ada. Sampai sekarang para guru PAI masih tetap berusaha untuk menumbuh kembangkan minat peserta didik untuk belajar membaca Alquran. Banyak metode yang digunakan sesuai dengan karakter anak yang mana metode tersebut sudah sesuai dengan harapan siswa, dengan metode Halaqoh atau membuat lingkaran bersama, metode tilawah, dan metode menghafal membantu siswa untuk belajar mengingat huruf Alquran, disinilah peran guru PAI yang sangat penting untuk membimbing dan mengarahkan siswa.

\section{REFERENSI}

Arifin. 2003. Ilmu Pendidikan Islam. Jakarta: Bumi Aksara

Arikunto, Suharsimi. 2006. Prosedur Penelitian Suatu Pendekaan Praktik. Jakarta: PT.Rineka Cipta

Darmaningtyas. 2005. Pendidikan Rusak-Rusakan. Yogjakarta: PTLkis Pelangi aksara

Hasan, M. Iqbal. 2002. Pokok-Pokok Materi: Metodologi penelitian dan Aplikasinya. Jakarta: Ghalia Indonesia

J Moleong, Lexy. 2000. Metodologi Kualitatif,. Bandung: PT Remaja Rosdakarya

Paturrohman, Pupuh. 2007. Strategi Belajar Mengajar. Bandung: PT Refika Aditama

Rusyan, Tabrani. 1989. Pendekatan dalam Proses Belajar Mengajar. Bandung: Remaja Rosdakarya

Subagio, Jogo. 2003. Metode Penelitian. Jakarta: Rineka Cipta

Sugiyono. 2007. Metodologi penelitian Pendidikan. Bandung: Alfabeta

Sukardi. 2009. Metodologi Penelitian Pendidikan: Kompetensi dan Praktiknya. Jakarta: Bumi Aksara

Tanzeh, Ahmad. 2009. Pengantar Metode Penelitian. Yogyakarta: Teras, 2009 